\title{
Identification of aberrant forms of alkaline sphingomyelinase (NPP7) associated with human liver tumorigenesis
}

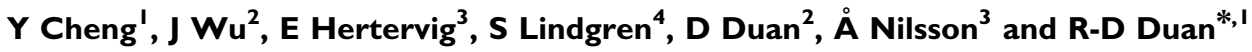 \\ 'Gastroenterology Lab, Biomedical Centre, BI I, Institute of Clinical Sciences, Lund University, Lund S-22I 84, Sweden; ${ }^{2}$ Beijing Institute of Biotechnology, \\ No. 20, Dong Dajie, Beijing 10007I, China; ${ }^{3}$ Gastroenterology Division, Institute of Clinical Sciences, Lund University, Lund S-22I 85, Sweden; \\ ${ }^{4}$ Gastroenterology Division, Department of Clinical Sciences, Lund University, Malmö S-20502, Sweden
}

\begin{abstract}
Alkaline sphingomyelinase (alk-SMase) is expressed in the intestine and human liver. It may inhibit colonic tumorigenesis, and loss of function mutations have been identified in human colon cancer. The present study investigates its expression in human liver cancer. In HepG2 liver cancer cells, RT-PCR identified three transcripts with 1.4, I.2 and $0.4 \mathrm{~kb}$, respectively. The $1.4 \mathrm{~kb}$ form is the wild-type cDNA with five translated exons, the $1.2 \mathrm{~kb}$ product lacks exon 4 and the $0.4 \mathrm{~kb}$ form is a combination of exons I and 5 . Genomic sequence showed that these aberrant transcripts were products of alternative splicing. Transient expression of the $1.2 \mathrm{~kb}$ form showed no alk-SMase activity. In HepG2 cells, the alk-SMase activity is low in monolayer condition and increased with cell polarisation. Coexistence of 1.4 and $1.2 \mathrm{~kb}$ forms was also identified in one hepatoma biopsy. GenBank search identified a cDNA clone from human liver tumour, which codes a protein containing full length of alk-SMase plus a 73-amino-acid tag at the $\mathrm{N}$ terminus. The aberrant form was translated by an alternative starting codon upstream of the wild-type mRNA. Expression study showed that linking the tag markedly reduced the enzyme activity. We also analysed human liver biopsy samples and found relatively low alkSMase activity in diseases with increased risk of liver tumorigenesis. In conclusion, expression of alk-SMase is changed in hepatic
\end{abstract} tumorigenesis, resulting in loss or marked reduction of the enzyme function.

British Journal of Cancer (2007) 97, |44 I- |448. doi: I0.1038/sj.bjc.66040 I3 www.bjcancer.com

Published online 9 October 2007

(c) 2007 Cancer Research UK

Keywords: alkaline sphingomyelinase; liver tumour; HepG2; liver diseases; human; ENPP7

Alkaline sphingomyelinase (alk-SMase), discovered in 1969, hydrolyses sphingomyelin (SM) at optimal alkaline $\mathrm{pH}$ (Nilsson, 1969). Recent cloning studies showed that the enzyme shares no similarities with other SMases but belongs to nucleotide pyrophosphatase/phosphodiesterase (NPP) family (Duan et al, 2003; Wu et al, 2005a). Being a novel member of the NPP family, it is also named NPP7 (Stefan et al, 2005). Alk-SMase is an ectoenzyme with a signal peptide at the $\mathrm{N}$ terminus and a hydrophobic domain at the $\mathrm{C}$ terminus. The $\mathrm{N}$-terminal signal peptide is important for transport of the enzyme to plasma membrane, whereas the $\mathrm{C}$ terminal hydrophobic domain is a signal anchor, which hooks the enzyme to the surface of plasma membrane (Duan et al, 2003; Wu et al, 2004b). The enzyme activity has been identified in the intestinal tract of many species (Duan et al, 1996) and human bile (Nyberg et al, 1996; Duan and Nilsson, 1997) but not in bile of other species such as pig, rat, mouse, rabbit, sheep and baboon. In agreement, northern blot has shown high levels of alk-SMase mRNA in human liver (Duan et al, 2003) but not in rat liver (Wu et al, 2005a). The enzyme appearing in the bile is believed to be released from liver by bile salt (Duan et al, 1998). The enzyme in the intestinal mucosa can also be released by trypsin, and the

*Correspondence: Dr R-D Duan; E-mail: Rui-dong.duan@med.lu.se Received 29 March 2007; revised 3 September 2007; accepted 6 September 2007; published online 9 October 2007 cleaved enzyme has higher activity than the mucosal form (Wu et al, 2004b).

Sphingomyelin metabolism generates both antiproliferative molecules such as ceramide and sphingosine and proliferative molecules such as sphingosine-1-phosphate, which are deeply involved in development of many types of tumour (Ogretmen and Hannun, 2004). Alk-SMase may function as a tumour suppressor through three mechanisms, as recently reviewed (Duan, 2006). First, it hydrolyses SM to generate ceramide, which inhibits cell proliferation, and induces apoptosis mainly by dephosphorylation and inactivation of many proliferative and antiapoptotic molecules such as protein kinase B (Akt), protein kinase $\mathrm{C}, \mathrm{Bcl}-2$ and $\mathrm{pRB}$ (Merrill et al, 1997; Pettus et al, 2002). Second, it hydrolyses and inactivates platelet-activating factor, a potent proinflammatory and proliferative molecule in the intestinal tract ( $\mathrm{Wu}$ et al, 2006). Finally, it degrades lysophosphatidylcholine by a phospholipase C activity, thus reducing the formation of lysophosphatidic acid, a potent factor that stimulates cell migration and angiogenesis (Duan, 2006; Wu et al, 2006). We previously found that alk-SMase activity was decreased in colonic adenomas and carcinomas, in familial adenomatous polyposis and in longstanding ulcerative colitis (Hertervig et al, 1997, 1999; Sjöqvist et al, 2002). The reduction was recently confirmed and the levels of alk-SMase in the faeces have been considered as a potential marker for diagnosis and prognosis of colon cancer (Di Marzio et al, 2005). The activity reduction may be a consequence of genetic perturbations, as an 
exon deletion that inactivates the enzyme has been found in HT29 colon cancer cells (Wu et al, 2004a).

While much attention has been paid to the enzyme in colon, little is known about the changes of the enzyme in human liver, the only organ except intestine that expresses alk-SMase (Duan et al, 1996, 2003; Wu et al, 2005a). Liver is important for generating endogenous SM and regulating the SM levels in the plasma (Nilsson and Duan, 2006), and previous studies have shown that SM metabolism is implicated in liver diseases. Sphingomyelin has been reported to protect hepatic cells against bile salts (Amigo et al, 1999; Moschetta et al, 2003). Animals ingesting food contaminated with mycotoxin fumonisin B, an inhibitor of ceramide synthesis, have an increased risk of liver cancer (Merrill et al, 1995; Gelderblom et al, 1996). Feeding animals with dietary $\mathrm{SM}$ reduced the formation of liver enzyme-altered foci, a hepatic marker of preneoplasia (Silins et al, 2003). Platelet-activating factor, another substrate for alk-SMase, has important implications in carbon tetrachloride-induced liver cirrhosis (Yang et al, 2004), endotoxin- and alcohol-induced hepatic apoptosis and necrosis (Murohisa et al, 2002), and liver metastasis of colon cancer (Denizot et al, 2005). The present study for the first time examines the expression of alk-SMase in human liver cancer cells and diseased liver tissues. Our results indicate that the expression of alk-SMase can be changed in human liver tumour and liver diseases, resulting in marked reduction of the enzyme activity.

\section{MATERIALS AND METHODS}

\section{Materials}

HepG2 and COS-7 cells were purchased from American Tissue Culture Collection. AK126250 clone was purchased from National Institute of Technology and Evaluation (Chiba, Japan). Antihuman alk-SMase antibody was generated by AgriSera $A B$ (Vännäs, Sweden) as described (Duan et al, 2003). Sphingomyelin was labelled with $\left[{ }^{14} \mathrm{C}-\mathrm{CH}_{3}\right]$ choline $\left(\left[{ }^{14} \mathrm{C}-\mathrm{SM}\right]\right)$ at Astra Zeneca, (Södertälje, Sweden) (Stoffel, 1975). Plasmid pcDNA4/TO/myc-His B, lipofectamine ${ }^{\mathrm{TM}}$ 2000, Ready-To-Go RT - PCR beads, Quickprep ${ }^{\mathrm{TM}}$ total RNA extraction kit, GFX ${ }^{\mathrm{TM}}$ DNA purification kit, primers used for PCR, and cell culture mediums were purchased from Invitrogen (Stockholm, Sweden). RNA stabilisation reagent (RNAlater ${ }^{\mathrm{TM}}$ ) was from Qiagen $\mathrm{GmbH}$ (Hilden, Germany). The western blotting kit was from Amersham Biosciences (Uppsala, Sweden). All other chemical agents were purchased from Sigma Co. (Stockholm, Sweden). Human liver biopsy samples were obtained from the University Hospitals in Lund and Malmö, under the ethical permission issued by the Regional Human Ethics committee and the consents of each patient.

\section{Methods}

Cell culture HepG2 and COS-7 cells were cultured in DMEM medium with $2 \mathrm{~mm}$ glutamine, $4500 \mathrm{mgl}^{-1}$ glucose, $100 \mathrm{IU} \mathrm{ml}^{-1}$ penicillin, $10 \mu \mathrm{g} \mathrm{ml}^{-1}$ streptomycin and $10 \%$ heat-inactivated foetal calf serum as described (Duan et al, 2003). Culturing HepG2 cells under polarising conditions was performed on the insert filters (3.0 $\mu \mathrm{m}$, Corning BV, The Netherlands) as described previously (Wu et al, 2004a). After culturing, the cells were scraped and centrifuged by 3000 r.c.f. at $4{ }^{\circ} \mathrm{C}$ for $10 \mathrm{~min}$. The pellets were lysed, sonicated and centrifuged as described (Liu et al, 2002). The activity of alk-SMase and the protein content were determined.

Amplification and cloning of alk-SMase cDNA from HepG2 cells HepG2 cells were suspended in RNAlater solution. Total RNA was extracted by Total RNA Extraction kit (Amersham Biosciences) and reversely transcripted to cDNA by a Thermoscript RT-PCR System (Invitrogen). Alk-SMase cDNA was amplified by PCR using sense primer $5^{\prime}$ tcggtaccgaaagcatgagagg cccggccgtcctc $3^{\prime}$ and antisense primer $5^{\prime}$ tagcggccgcctgcgacctcaga cagaagaat $3^{\prime}$ according to the cDNA sequence of alk-SMase gene (GenBank AY230663) with the cDNAs as templates. The PCR products were isolated by $1 \%$ agarose gel electrophoresis and each band was purified by GFX DNA purification kit. The products were digested with KpnI/NotI and constructed into KpnI and NotI sites of pcDNA4/TO/myc-His plasmid. The cDNA inserts were sequenced by Cybergene (Huddinge, Sweden) using sense $5^{\prime} \mathrm{cgc}$ aaatgggcggtaggcgtg $3^{\prime}$ and antisense $5^{\prime}$ tagaaggcacagtcgagg $3^{\prime}$ primers of the vector and an alk-SMase primer $5^{\prime}$ ggtggtgggacaacggca3' from the site 349-367, based on the gene sequence of human alk-SMase (Duan et al, 2003) (GenBank AY230663).

Genomic alk-SMase DNA extraction and sequence The genomic DNA of HepG2 cells was examined as described previously (Wu et al, 2004a). The cells were lysed and the lysate were used as template. The genomic DNA of alk-SMase gene from exon 3 to exon 5 was amplified by PCR using sense $5^{\prime}$ cacggcatgacgaccg tggacaaac $3^{\prime}$ and antisense $5^{\prime}$ tagcggccgcctgcgacctcagacagaagaat $3^{\prime}$ primers according to the genomic sequence of ENPP7 in GenBank (NM_178543). The $2.6 \mathrm{~kb}$ PCR product was sequenced by Cybergene with sense $5^{\prime}$ cacggcatgacgaccgtggacaaac $3^{\prime}$ and $5^{\prime}$ gccttcc actacgccaacaa $3^{\prime}$, and antisense $5^{\prime}$ tagcggccgcctgcgacctcagacagaagaa $\mathrm{t} 3^{\prime}$, and $5^{\prime}$ tgcatgaggtgctcgtgaga $3^{\prime}$ primers.

Transient expression COS-7 cells, which do not express endogenous alk-SMase, were transfected with $4 \mu \mathrm{g}$ of the constructed plasmids with the PCR products identified from HepG2 cells or the clone AK126250 by the lipofectamine as described previously (Duan et al, 2003). Control cells were transfected with the mock plasmid in the same way as the transfected cells. The cells were then cultured for $48 \mathrm{~h}$, scraped and lysed as described (Duan et al, 2003). The activities of alk-SMase in the cell-free extracts were determined. The efficiency of the transfection was monitored by either western blotting or the simultaneous transfection of Lac-Z gene followed by $\beta$-galactosidase analysis.

Liver sample preparation For alk-SMase assay, human liver biopsy samples were homogenised in $50 \mathrm{~mm}$ Tris- $\mathrm{HCl}$ buffer containing $2 \mathrm{~mm}$ EDTA, $1 \mathrm{~mm}$ PMSF, $1 \mathrm{~mm}$ benzamidine, $0.5 \mathrm{~mm}$ dithiotheritol and $2.5 \mathrm{mg} \mathrm{ml}^{-1}$ bile salts, followed by sonication for 10 s. The sonicates were centrifuged at 10000 r.c.f. for $10 \mathrm{~min}$ and the supernatants were saved for biochemical analysis.

Determination of SMase, galactosidase and proteins The activities of acid, neutral and alk-SMase were determined as described, using choline-labelled SM $\left(\left[{ }^{14} \mathrm{C}-\mathrm{SM}\right]\right)$ as substrate in different assay buffers (Duan and Nilsson, 2000; Liu et al, 2006). The activity of $\beta$-galactosidase in COS-7 cells after transfection was assayed by a $\beta$-gal assay kit (Invitrogen), using ortho-nitrophenyl- $\beta$-galactopyranoside as substrate ( $\mathrm{Wu}$ et al, 2004a). The protein was analysed by a kit from Bio-Rad (Sundbyberg, Sweden) using bovine albumin as a standard.

Western blot Western blot for alk-SMase was performed as described (Duan et al, 2003). In brief, the cell lysate containing $50 \mu \mathrm{g}$ cellular proteins was subjected to $10 \%$ SDS - polyacrylamide gel electrophoresis and then transferred to a nitrocellulose membrane electrophoretically. After blocking, the membrane was probed with anti-human SMase antibody $(1: 2500)$ and then reacted with rabbit IgG antibody $(1: 50000)$ conjugated with horseradish peroxidase. The alk-SMase bands were identified by ECL advanced reagents and the emitted light was recorded on Kodak X-ray film. When necessary, the membranes were then stripped and reprobed with anti-actin antibody as a loading control. 


\section{RESULTS}

\section{Expression of alk-SMase in HepG2 liver cancer cells}

After RT - PCR in total RNA isolated from HepG2 liver cancer cells, three products of $1.4,1.2$ and $0.4 \mathrm{~kb}$ were identified by agarose gel electrophoresis (Figure 1, upper panel). Each product was then purified, cloned and sequenced. The results are shown in the lower panel of Figure 1 . The $1.4 \mathrm{~kb}$ form turned out to be a wild-type cDNA of alk-SMase, which contains five translated exons as indicated. The $1.2 \mathrm{~kb}$ form is a product with exon 4 truncated. The $0.4 \mathrm{~kb}$ form is only a link of exons 1 and 5 . Both 1.4 and $1.2 \mathrm{~kb}$ forms were then subcloned and transiently expressed in COS-7 cells. Expression of the $1.4 \mathrm{~kb}$ cDNA demonstrated high alk-SMase activity, whereas expression of the mutant $1.2 \mathrm{~kb}$ form showed no alk-SMase activity (Figure 2). The similar activity of $\beta$-galactosidase in both cases (Figure 2, middle panel) as well as the Western blot (Figure 2, bottom panel) confirms that the abolishment of alk-SMase activity of $1.2 \mathrm{~kb}$ was not caused by the insufficient transfection.

To further address whether the formation of the $1.2 \mathrm{~kb}$ form is caused by genomic mutation, the genomic domain between exons 3 and 5 in HepG2 cells was extracted by PCR and sequenced. No mutation at genomic level was identified (data not shown). The $1.2 \mathrm{~kb}$ form was therefore caused by an alternative splicing.

Since both wild-type and mutant alk-SMase mRNAs were identified in HepG2 cells, the expression of the wild-type enzyme in the cells was examined in both monolayer and polarised conditions. As shown in Figure 3, the activity of alk-SMase was low in monolayer cells and was maximal at about $80 \%$ confluence $(6$ days) and then declined when the culturing was continued. However, in the cells cultured in polarised conditions, the alkSMase activity was significantly increased with the time. The results indicate that the expression of the wild-type alk-SMase is associated with differentiation.

How often the alternative $1.2 \mathrm{~kb}$ mRNA occurs in different types of liver cancer is unknown, since the answer to this question requires studies of a large number of liver tumours, which are not very common in Sweden. In a preliminary study, we performed similar PCR using a cDNA template isolated from a hepatoma tissue of a patient with autoimmune hepatitis. Two PCR products with the size of 1.4 and $1.2 \mathrm{~kb}$ were identified (Figure 4, upper left).
The two products were then purified, amplified by PCR (Figure 4, lower left panel) and sequenced. We found that the $1.4 \mathrm{~kb}$ is the wild-type mRNA, whereas the $1.2 \mathrm{~kb}$ is identical to that found in
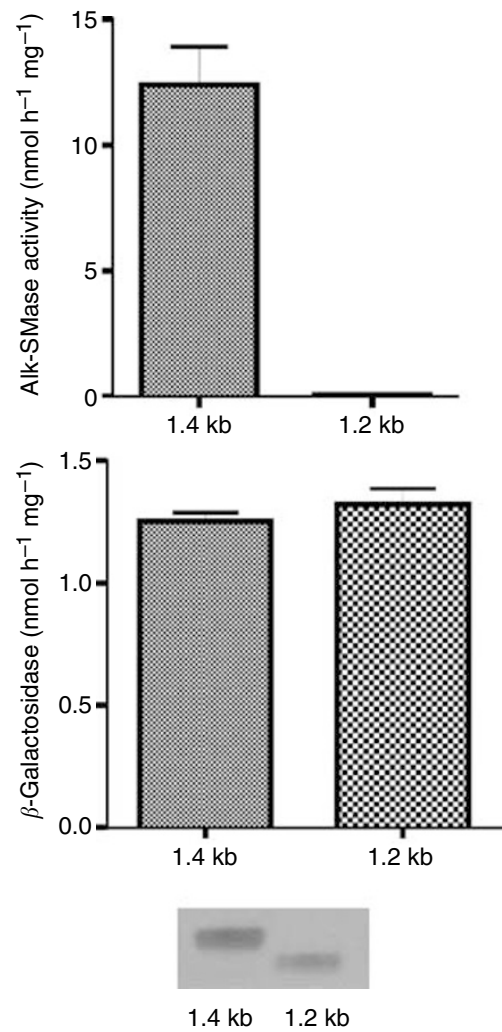

Figure 2 Transient expression of the wild-type and the mutant form of alk-SMase mRNA in COS-7 cells. The 1.4 and $1.2 \mathrm{~kb}$ transcript found in HepG2 cells were purified, cloned and constructed in pcDNA4/TO/mycHis. After transfecting COS-7 cells for $48 \mathrm{~h}$ culture, the cells were lysed and the activities of alk-SMase (upper panel) and $\beta$-galactosidase (middle panel) were determined. Western blot of the cell lysate for alk-SMase was performed (bottom panel). Results for activity assay were mean \pm s.e.m. from three separate experiments.
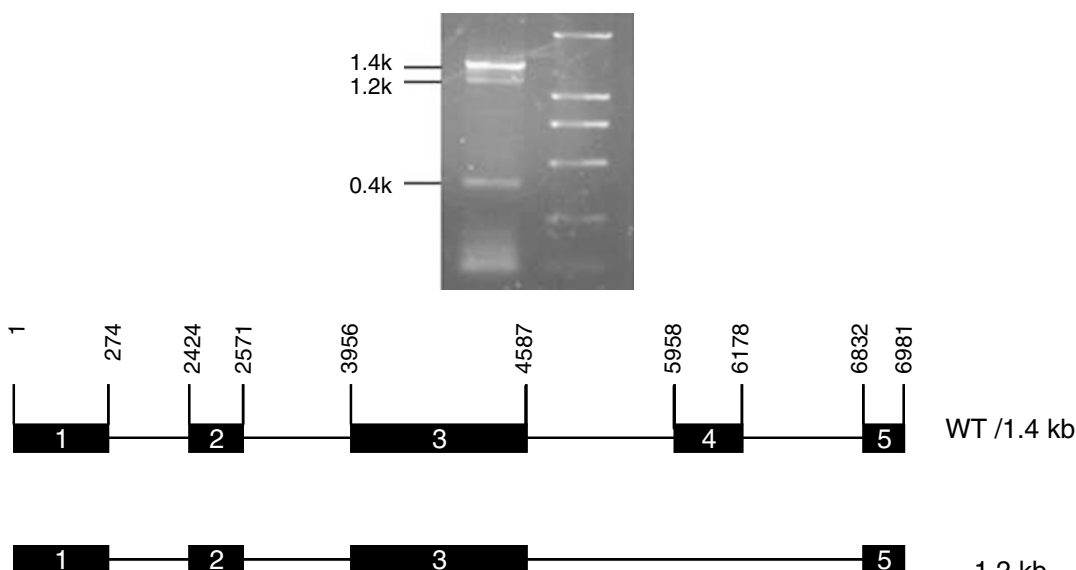

Figure I Identification of alk-SMase cDNA in HepG2 cells. Total RNA was extracted from HepG2 cells and alk-SMase cDNA was amplified by RT-PCR. The PCR products were visualised by $1 \%$ agarose gel electrophoresis (upper panel). The lower panel shows the exons found in the PCR products based on DNA sequence data. The black boxes indicate the translated exon and the order of the exon is indicated. 


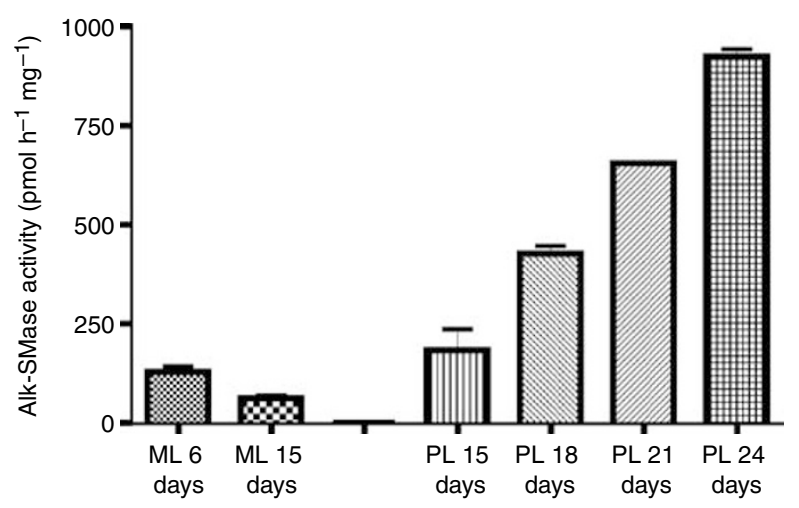

Figure 3 Expression of alk-SMase in HepG2 cells. HepG2 cells were cultured in both monolayer for 6 (80\% confluence) and 15 days, and in polarised conditions for 15, 18, 21 and 24 days. The cell-free extracts were prepared and alk-SMase activity in the cell lysate was determined. $\mathrm{ML}$, monolayer; PL, polarised. The days of culturing were indicated. Results are mean \pm s.e.m. form duplicate determinations in three separate experiments.
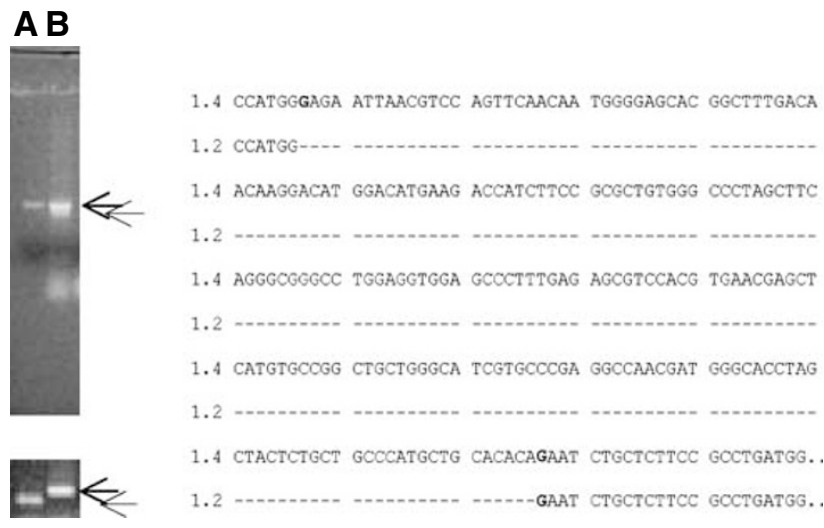

Figure 4 Identification of alk-SMase cDNA in one hepatoma tissue from a patient with autoimmune hepatitis. The alk-SMase cDNA was amplified by PCR using the total CDNA isolated from the tissue as a template. The PCR products were visualised by $1 \%$ agarose electrophoresis (left panel). The two PCR products were further purified and amplified by second PCR (lower left panel). The difference in cDNA sequence is shown on the right panel, which shows the absence of exon 4. (A) cDNA of wild-type alkSMase as a template. (B) cDNA of the hepatoma as a template. The two arrows indicate the 1.4 and $1.2 \mathrm{~kb}$ forms identified.

A MLKLIPPHAR EAGTRGGTDT AGEPTPEVRP GDVHSHIPKA HGMRSAWVTL GLCPPRQEPA LCTLCACPSG RPSMRGPAVL LTVALATLLA PGAGAPVQSQ GSQNKLLLVS FDGFRWNYDQ DVDTPNLDAM ARDGVKARYM TPAFVTMTSP CHFTLVTGKY IENHGVVHNM YYNTTSKVKL PYHATLGIQR WWDNGSVPIW ITAQRQGLRA GSFFYPGGNV TYQGVAVTRS RKEGIAHNYK NETEWRANID TVMAWFTEED LDLVTLYFGE PDSTGHRYGP ESPERREMVR QVDRTVGYLR ESIARNHLTD RLNLIITSDH GMTTVDKRAG DLVEFHKFPN FTFRDIEFEL LDYGPNGMLL PKEGRLEKVY DALKDAHPKL HVYKKEAFPE AFHYANNPRV TPLLMYSDLG YVIHGRINVQ FNNGEHGFDN KDMDMKTIFR AVGPSFRAGL EVEPFESVHV NELMCRLLGI VPEANDGHLA TLLPMLHTES ALPPDGRPTL LPKGRSALPP SSRPLLVMGL LGTVILLSEV

B

AGATGCTCAA GTTGATACCA CCCCACGCAC GTGAGGCTGG GACCAGGGGT GGCACTGACA CGGCTGGGGA GCCCACTCCC GAGGTTCGAC CCGGGGATGT GCACAGCCAC ATtCCAAAGg CGCACGgGAT GAGATCAGCC TGGGTGACCC TGgGACtTtg tCCTCCTCGg CAgGAgCCAg CCCTGtgCAC CCTGTGtgCC TGTCCATCTG GAAGGCCCAG CATGAGAGGC CCGGCCGTCC TCCTCACTGT GGCTCTGGCC ACGCTCCTGG CTCCCGGGGC CGGAGCACCG ......

Figure 5 The amino-acid and CDNA sequences of AKI 26250 clone identified in liver tumour. The panel $\mathbf{A}$ shows the full length of amino-acid sequence of AKI 26250. The underlined sequence indicates the N-terminal tag that links to the wild-type alk-SMase. The panel B displays part of the cDNA sequence of AKI26250. The start codon of the protein is in bold, and that of the wild-type alk-SMase is in bold and underlined. 
HepG2 cells, without exon 4 (Figure 4 , right panel). The results indicate that the $1.2 \mathrm{~kb}$ aberrant form can be identified in human liver cancer tissue.

\section{Expression of a 'big' alk-SMase in liver tumour}

By FIS (full-length insert sequence) searching in the GenBank, we found a cDNA clone (GenBank AK126250) with $2031 \mathrm{bp}$ that encodes full length of alk-SMase plus a 73-amino-acid tag linked to the $\mathrm{N}$ terminus of the enzyme (Figure 5, upper panel). The clone for this 'big' alk-SMase was identified from a human liver tumour. Looking at the genomic sequence, we found that the big alk-SMase is translated by an alternative start codon, which is located upstream of the wild-type mRNA of alk-SMase (Figure 5, lower panel). To investigate whether this protein has alk-SMase activity, the cDNA clone was purchased and expressed in COS-7 cells. As shown in the box of Figure 6, the alk-SMase activity in the cells transfected with AK126250 was three-fold higher than that in control cells but still much lower than that in the cells transfected with wild-type alk-SMase. Western blot clearly showed that the AK126250 protein had been expressed to similar level as the wildtype alk-SMase cDNA (Figure 6, lower panel). Since the N terminus of wild-type alk-SMase contains a transmembrane domain that serves as a signal peptide, TM-pred analysis was performed for AK126250 protein. As shown in Figure 7, linking the 73 residues at the N-terminal changes the hydrophobic feature of the enzyme. The big alk-SMase no longer has a signal peptide at the $\mathrm{N}$ terminus.

We also examined whether the big alk-SMase is expressed in HepG2 cells by RT-PCR using new sense primer $5^{\prime}$ tcggta ccgaaagcatgctcaagttgataccac $3^{\prime}$ and the wild-type antisense primer according to the sequence of the big enzyme. No PCR product with correct size was identified, indicating that this type of alk-SMase is not expressed in HepG2 cells (data not shown).

\section{Alk-SMase activity in liver diseases}

For addressing a question whether alk-SMase activity is detectable in human liver biopsies, three types of SMase were analysed in

\begin{tabular}{|lcc|}
\hline \multicolumn{2}{|c|}{ Alk-SMase activity $\left(\mathrm{pmol} \mathrm{h}{ }^{-1} \mathrm{mg}^{-1}\right)$ after transfection } \\
\hline & Activity & $n$ \\
\hline Control & $29.4 \pm 1.6$ & 4 \\
AK126250 & $95.2 \pm 2.5$ & 4 \\
WT alk-SMase & $12046 \pm 98.5$ & 2 \\
\hline
\end{tabular}

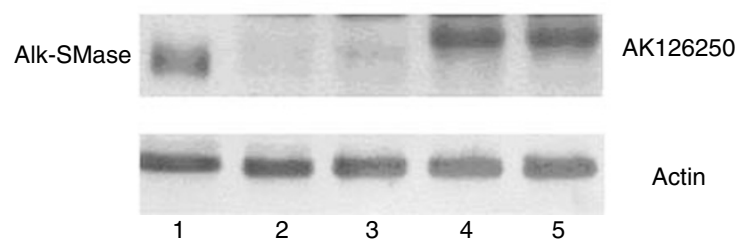

Figure 6 Expression of CDNA of wild-type alk-SMase and the AKI26250 in COS-7 cells. COS-7 cells were transfected with the wildtype and AKI 26250 cDNA. The alk-SMase activities in the lysates $24 \mathrm{~h}$ after transfection were determined and the results are shown in the box of the upper panel. The expressed wild-type alk-SMase and the AKI26250 proteins were shown by Western blot in the lower panel. Lane I: wild-type alk-SMase expressed in COS-7 cells. Lanes 2 and 3: control COS-7 cells. Lanes 4 and 5: AK 126250 expressed in COS-7 cells. A loading control by probing the membrane with anti-actin was shown below.
30 biopsy samples. The results with the diagnosis are shown in Table 1. The activity of alk-SMase was detectable in liver biopsies and was high comparing with acid and neutral SMase. Although not conclusive due to the number of the samples, alk-SMase activity appeared particularly high in cholestatic liver disease excluding primary sclerosing cholangitis (PSC) $\left(2.83 \pm 1.4 \mathrm{nmol} \mathrm{h}^{-1} \mathrm{mg}^{-1}\right)$ and low in steatosis $(0.41 \pm 0.1 \mathrm{nmol}$ $\left.\mathrm{h}^{-1} \mathrm{mg}^{-1}\right)$ and PSC $\left(0.72 \pm 0.37 \mathrm{nmol} \mathrm{h}^{-1} \mathrm{mg}^{-1}\right)$. The activity did not correlate with most biochemical examinations, except that a positive correlation with $\alpha$-antitrypsin was identified $\left(r^{2}=0.1658\right.$, $P=0.0350)$.

\section{DISCUSSION}

Alk-SMase is specifically expressed in the intestinal tract and human liver. The clinical implications of the enzyme in intestinal tumours have been a topic under the last decade. The accumulating evidence indicates that, in the intestinal tract, alk-SMase may prevent colonic tumorigenesis. First, the enzyme generates antiproliferative and proapoptotic lipid messenger ceramide (Duan et al, 2003; Hertervig et al, 2003). Second, the enzyme inhibits proliferation of human colon cancer cells (Hertervig et al, 2003). Third, the enzyme activity is reduced in both longstanding ulcerative colitis and colonic tumorigenesis (Hertervig et al, 1997, 1999; Sjöqvist et al, 2002). And finally, mutation has been
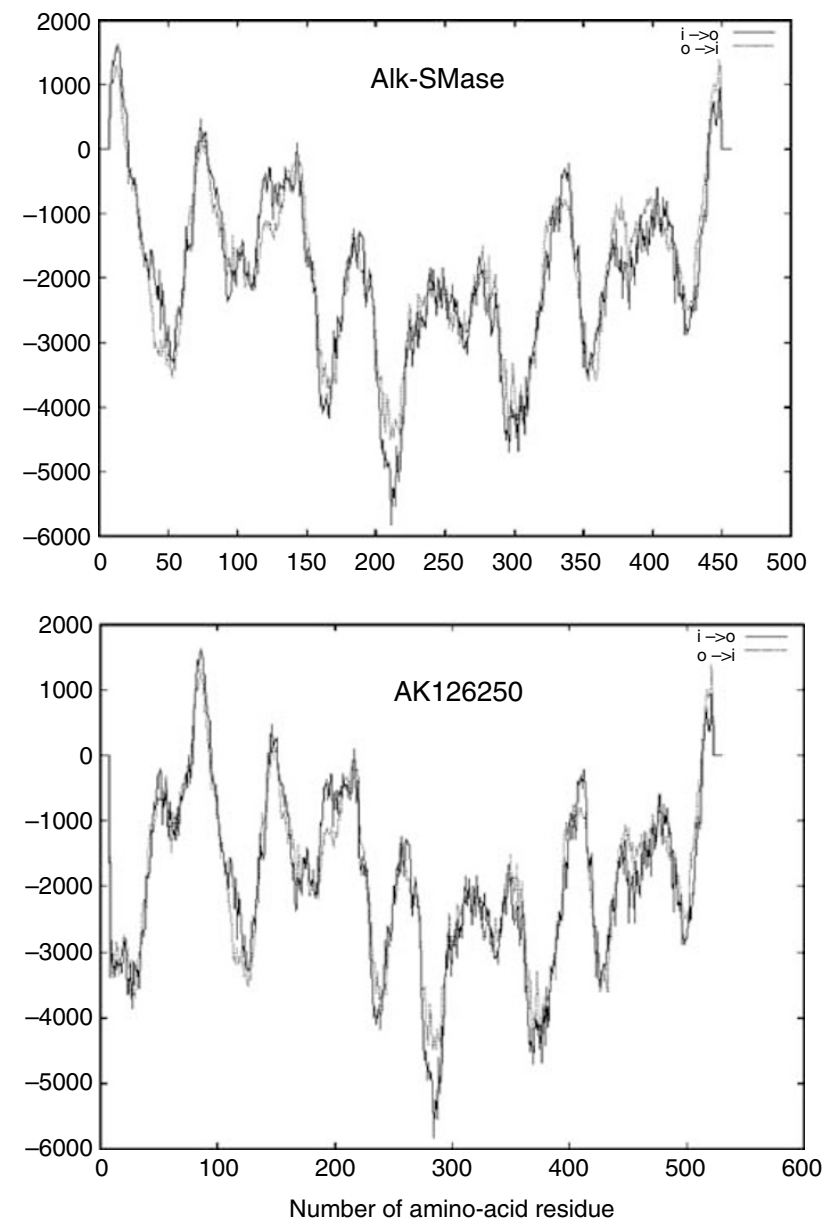

Figure 7 Comparison of the TM-pred analysis of $\mathrm{N}$-terminal transmembrane domains of wild-type alk-SMase and AKI26250 protein. The X-axis is the amino-acid sequences of the proteins and the $Y$-axis is the hydrophobicity of the amino-acid residues. 
Table I SMase activity $\left(\mathrm{nmol} \mathrm{h} \mathrm{hg}^{-1} \mathrm{mg}^{-1}\right.$ in liver biopsy samples

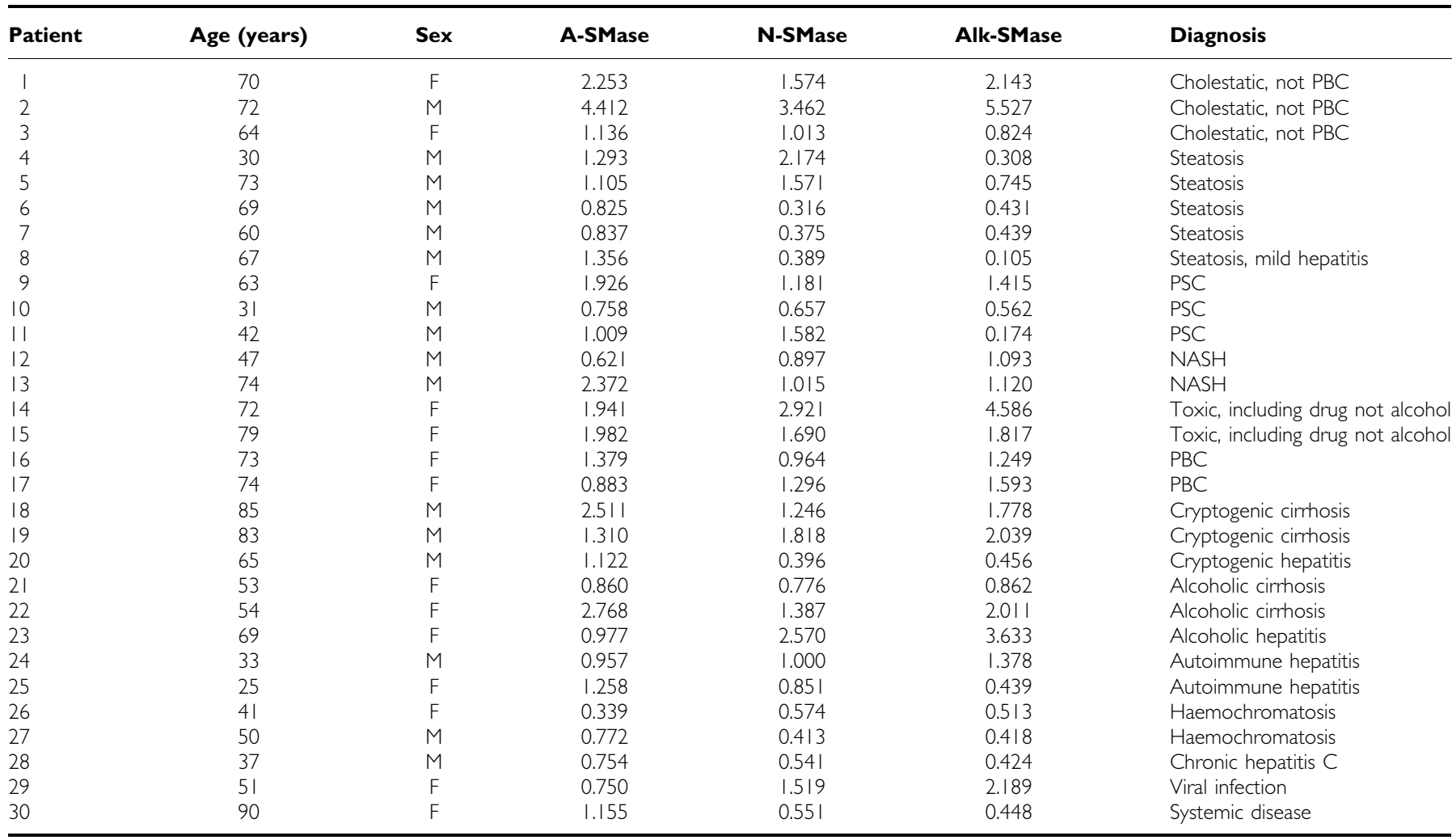

A-SMase = acid sphingomyelinase; Alk-SMase = alkaline sphingomyelinase; $F=$ female; $M=$ male; $P B S=$ primary biliary cirrhosis; $P S C=$ primary sclerosing cholangitis; $\mathrm{NASH}=$ non-alcoholic steatohepatitis; N-SMase = neutral sphingomyelinase.

identified in colon cancer cells, which abolishes the enzyme activity (Wu et al, 2004a).

Human liver is the only organ except the intestine that expresses alk-SMase. It is both a site of primary tumours and the most common site of colon cancer metastasis. It is well-known that PSC increases the risk of hepatobiliary cancer (Yang et al, 2001; Ohata et al, 2003; Lazaridis and Gores, 2006) as well as colon cancer associated with colitis (Broome and Bergquist, 2006). The disease is treated with ursodeoxycholic acid to decrease the risk of colorectal cancer (Pardi et al, 2003) and ursodeoxycholic acid has been shown to induce expression alk-SMase in both animal models and cell culture studies (Cheng et al, 1999; Liu et al, 2006). We therefore raised a question whether this ectoenzyme may also be an antitumour factor both in development of primary hepatic and biliary carcinomas and in the regulation of metastatic tumour growth. To answer the question, it is important to study the expression of the enzyme associated with liver cancer and precancerous diseases.

In this study, we showed that HepG2 liver cancer cells have both wild-type $(1.4 \mathrm{~kb})$ and mutant forms $(1.2$ and $0.4 \mathrm{~kb})$ of alk-SMase transcript. The identification of the $1.2 \mathrm{~kb}$ form may have special importance, because it is an inactive form and it resembles the mutation previously identified in HT29 colon cancer cells (Wu et al, 2004a). Although the mutations found in HepG2 and HT29 cells are not identical, both mutations involve a deletion of exon 4 . We previously showed that the amino acid His at 353 position in exon 4 is critical for the enzyme function, and site mutation of H353 abolishes the enzyme activity (Wu et al, 2004a). H353 in fact participates in the formation of two metal coordinate sites, and recent studies showed that metal ion sites in NPP family may play important roles in substrate binding (Zalatan et al, 2006). It is therefore expected that the protein encoded by the $1.2 \mathrm{~kb}$ form showed no alk-SMase activity. The similar exon 4 deletion in both liver and colon cancer cells casts light on the close link of colon and liver in tumorigenesis. Unlike HT29 colon cancer cells, HepG2 cells also express the wild-type alk-SMase. The expression rate is low under monolayer conditions, but increased when the cells are under polarising, that is, differentiating conditions. The finding is in agreement with our previous study on Caco-2 cells (Wu et al, 2004a). Thus, the factors that inhibit the differentiation of liver cells may suppress the expression of alk-SMase.

The present study also characterised another form of alk-SMase registered in GenBank, which was identified in a liver tumour. The cDNA clone encodes the full length of the enzyme plus 73-aminoacid residues linking to the $\mathrm{N}$ terminus. It is translated from an alternative starting codon upstream of the wild-type mRNA. Although transient expression showed some activity of the big alkSMase, but the activity was much lower than the wild-type enzyme. The reduction may be caused by the change of the hydrophobicity of alk-SMase at the $\mathrm{N}$ terminus, leading to loss of a signal peptide, which regulates the traffic of the enzyme to endoplasmic reticulum for glycosylation and to the plasma membrane for secretion ( $\mathrm{Wu}$ et al, 2005b). Without the signal peptide, the enzyme may not be properly transported and glycosylated. Normal transportation and glycosylation are important factors for full activity of the enzyme (Wu et al, 2005b)

By measuring acid, neutral and alkaline SMase activities in human liver biopsy samples, we showed that alk-SMase activity is detectable in human liver biopsies. The activity is high and at least equal to that of acid SMase, which is known to be highly expressed in the liver (Spence et al, 1979). The biopsy samples examined were taken from patients with different liver diseases. The number of observations was too small to conclusively identify differences in alk-SMase expression among different diseases. However, relatively low activities were indicated in steatosis and PSC, which increases risk for hepatocellular carcinoma (Yang et al, 2001; 
Ohata et al, 2003) and cholangiocarcinoma (Lazaridis and Gores, 2006), respectively. The finding may indicate an early reduction of the enzyme activity in precancerous diseases in the liver. AlkSMase activity in general did not significantly correlate with many of the routine liver tests, but positively with the level of $\alpha$ antitrypsin. The significance of this finding is unknown. Since liver cells express trypsin-like protein (Leytus et al, 1988) and trypsin has been shown to dissociate alk-SMase from the intestinal mucosa (Wu et al, 2004b), anti-trypsin may prevent alk-SMase from release and thus increase its levels.

By examining a cDNA sample isolated from a biopsy of hepatocellular carcinoma, we did find similar coexistence of 1.4 and $1.2 \mathrm{~kb}$ mRNA of alk-SMase in the tissue, indicating that such mutation does occur in human liver cancer tissues. So far we have, however, not had access to enough human liver tumours to provide data on the frequency of different alk-SMase mutations in such tumours. Obviously this is an important issue for further studies.

\section{REFERENCES}

Amigo L, Mendoza H, Zanlungo S, Miquel JF, Rigotti A, Gonzalez S, Nervi F (1999) Enrichment of canalicular membrane with cholesterol and sphingomyelin prevents bile salt-induced hepatic damage. J Lipid Res 40: $533-542$

Broome U, Bergquist A (2006) Primary sclerosing cholangitis, inflammatory bowel disease, and colon cancer. Semin Liver Dis 26: 31-41

Cheng Y, Tauschel HT, Nilsson A, Duan RD (1999) Administration of ursodeoxycholic acid increases the activities of alkaline sphingomyelinase and caspase-3 in rat colon. Scand J Gastroenterol 34: $915-920$

Denizot Y, Descottes B, Truffinet V, Valleix D, Labrousse F, Mathonnet M (2005) Platelet-activating factor and liver metastasis of colorectal cancer. Int J Cancer 113: 503-505

Di Marzio L, Di Leo A, Cinque B, Fanini D, Agnifili A, Berloco P, Linsalata M, Lorusso D, Barone M, De Simone C, Cifone MG (2005) Detection of alkaline sphingomyelinase activity in human stool: proposed role as a new diagnostic and prognostic marker of colorectal cancer. Cancer Epidemiol Biomarkers Prev 14: 856-862

Duan RD (2006) Alkaline sphingomyelinase: an old enzyme with novel implications. Biochim Biophys Acta 1761: 281-291

Duan RD, Bergman T, Xu N, Wu J, Cheng Y, Duan J, Nelander S, Palmberg C, Nilsson A (2003) Identification of human intestinal alkaline sphingomyelinase as a novel ecto-enzyme related to the nucleotide phosphodiesterase family. J Biol Chem 278: $38528-38536$

Duan RD, Cheng Y, Tauschel HD, Nilsson A (1998) Effects of ursodeoxycholate and other bile salts on levels of rat intestinal alkaline sphingomyelinase: a potential implication in tumorigenesis. Dig Dis Sci 43: $26-32$

Duan RD, Hertervig E, Nyberg L, Hauge T, Sternby B, Lillienau J, Farooqi A, Nilsson A (1996) Distribution of alkaline sphingomyelinase activity in human beings and animals. Tissue and species differences. Dig Dis Sci 41: $1801-1806$

Duan RD, Nilsson $\AA$ (1997) Purification of a newly identified alkaline sphingomyelinase in human bile and effects of bile salts and phosphatidylcholine on enzyme activity. Hepatology 26: 823-830

Duan RD, Nilsson A (2000) Sphingolipid hydrolyzing enzymes in the gastrointestinal tract. Methods Enzymol 311: 276-286

Gelderblom WCA, Snyman SD, Abel S, Lebepe-Mazur S, Smuts CM, van der Westhuizen L, Marasas W, Victor TC, Knasmüller S, Huber W (1996) Hepatotoxicity and carcinogenicity of the fumonisins in rats. In Fumonisins in Food, Lackson L et al (eds), pp 279-296. New York: Plenum Press

Hertervig E, Nilsson Å, Björk J, Hultkrantz R, Duan RD (1999) Familial adenomatous polyposis is associated with a marked decrease in alkaline sphingomyelinase activity: a key factor to the unrestrained cell proliferation. Br J Cancer 81: $232-236$

Hertervig E, Nilsson A, Cheng Y, Duan RD (2003) Purified intestinal alkaline sphingomyelinase inhibits proliferation without inducing apoptosis in HT-29 colon carcinoma cells. J Cancer Res Clin Oncol 129: $577-582$
In conclusion, our results identified mutations of alk-SMase in liver tumorigenesis, resulting in significant reduction of the enzyme activity. The identification of similar deletion of exon 4 in colon and liver cancers may give insight into the frequent liver metastasis of colon cancer. Further investigations with larger number of tissue samples should focus on type and frequency of the mutations and their pathological implications in both cancer and precancerous liver diseases.

\section{ACKNOWLEDGEMENTS}

The work was supported by grants from Swedish Cancer Society, Albert Påhlsson Foundation, Swedish Research Council, Gunnar Nilssons Cancer Foundation and the Research Foundation of Lund University Hospital.
Hertervig E, Nilsson A, Nyberg L, Duan RD (1997) Alkaline sphingomyelinase activity is decreased in human colorectal carcinoma. Cancer 79: $448-453$

Lazaridis KN, Gores GJ (2006) Primary sclerosing cholangitis and cholangiocarcinoma. Semin Liver Dis 26: $42-51$

Leytus SP, Loeb KR, Hagen FS, Kurachi K, Davie EW (1988) A novel trypsin-like serine protease (hepsin) with a putative transmembrane domain expressed by human liver and hepatoma cells. Biochemistry 27: $1067-1074$

Liu F, Cheng Y, Wu J, Tauschel HD, Duan RD (2006) Ursodeoxycholic acid differentially affects three types of sphingomyelinase in human colon cancer Caco 2 cells. Cancer Lett 235: 141-146

Liu JJ, Nilsson A, Oredsson S, Badmaev V, Zhao WZ, Duan RD (2002) Boswellic acids trigger apoptosis via a pathway dependent on caspase-8 activation but independent on Fas/Fas ligand interaction in colon cancer HT-29 cells. Carcinogenesis 23: 2087-2093

Merrill Jr AH, Schmelz EM, Dillehay DL, Spiegel S, Shayman JA, Schroeder JJ, Riley RT, Voss KA, Wang E (1997) Sphingolipids - the enigmatic lipid class: biochemistry, physiology, and pathophysiology. Toxicol Appl Pharmacol 142: $208-225$

Merrill Jr AH, Schmelz EM, Wang E, Schroeder JJ, Dillehay DL, Riley RT (1995) Role of dietary sphingolipids and inhibitors of sphingolipid metabolism in cancer and other diseases. J Nutr 125: 1677S - 1682S

Moschetta A, Portincasa P, van Erpecum KJ, Debellis L, VanbergeHenegouwen GP, Palasciano G (2003) Sphingomyelin protects against apoptosis and hyperproliferation induced by deoxycholate: potential implications for colon cancer. Dig Dis Sci 48: 1094-1101

Murohisa G, Kobayashi Y, Kawasaki T, Nakamura S, Nakamura H (2002) Involvement of platelet-activating factor in hepatic apoptosis and necrosis in chronic ethanol-fed rats given endotoxin. Liver 22: 394-403

Nilsson $\AA$ (1969) The presence of sphingomyelin- and ceramide-cleaving enzymes in the small intestinal tract. Biochim Biophys Acta 176: 339-347

Nilsson A, Duan RD (2006) Absorption and lipoprotein transport of sphingomyelin. J Lipid Res 47: 154-171

Nyberg L, Duan RD, Axelsson J, Nilsson $\AA$ (1996) Identification of an alkaline sphingomyelinase activity in human bile. Biochim Biophys Acta 1300: $42-48$

Ogretmen B, Hannun YA (2004) Biologically active sphingolipids in cancer pathogenesis and treatment. Nat Rev Cancer 4: 604-616

Ohata K, Hamasaki K, Toriyama K, Matsumoto K, Saeki A, Yanagi K, Abiru S, Nakagawa Y, Shigeno M, Miyazoe S, Ichikawa T, Ishikawa H, Nakao K, Eguchi K (2003) Hepatic steatosis is a risk factor for hepatocellular carcinoma in patients with chronic hepatitis $\mathrm{C}$ virus infection. Cancer 97: 3036-3043

Pardi DS, Loftus Jr EV, Kremers WK, Keach J, Lindor KD (2003) Ursodeoxycholic acid as a chemopreventive agent in patients with ulcerative colitis and primary sclerosing cholangitis. Gastroenterology 124: $889-893$

Pettus BJ, Chalfant CE, Hannun YA (2002) Ceramide in apoptosis: an overview and current perspectives. Biochim Biophys Acta 1585: 114- 125 
Silins I, Nordstrand M, Hogberg J, Stenius U (2003) Sphingolipids suppress preneoplastic rat hepatocytes in vitro and in vivo. Carcinogenesis 24: $1077-1083$

Sjöqvist U, Hertervig E, Nilsson A, Duan RD, Ost A, Tribukait B, Lofberg R (2002) Chronic colitis is associated with a reduction of mucosal alkaline sphingomyelinase activity. Inflamm Bowel Dis 8: 258-263

Spence MW, Burgess JK, Sperker ER (1979) Neutral and acid sphingomyelinases: somatotopographical distribution in human brain and distribution in rat organs. A possible relationship with the dopamine system. Brain Res 168: $543-551$

Stefan C, Jansen S, Bollen M (2005) NPP-type ectophosphodiesterases: unity in diversity. Trends Biochem Sci 30: $542-550$

Stoffel W (1975) Chemical synthesis of choline-labeled lecithins and sphingomyelin. Methods Enzymol 36: 533 - 541

Wu J, Cheng Y, Nilsson A, Duan RD (2004a) Identification of one exon deletion of intestinal alkaline sphingomyelinase in colon cancer HT-29 cells and a differentiation-related expression of the wild-type enzyme in Caco-2 cells. Carcinogenesis 25: $1327-1333$

Wu J, Cheng Y, Palmberg C, Bergman T, Nilsson A, Duan RD (2005a) Cloning of alkaline sphingomyelinase from rat intestinal mucosa and adjusting of the hypothetical protein XP_221184 in GenBank. Biochim Biophys Acta 1687: 94-102
Wu J, Hansen GH, Nilsson A, Duan RD (2005b) Functional studies of human intestinal alkaline sphingomyelinase by deglycosylation and mutagenesis. Biochem J 386: $153-160$

Wu J, Liu F, Nilsson A, Duan RD (2004b) Pancreatic trypsin cleaves intestinal alkaline sphingomyelinase from mucosa and enhances the sphingomyelinase activity. Am J Physiol Gastrointest Liver Physiol 287: G967-G973

Wu J, Nilsson A, Jonsson BA, Stenstad H, Agace W, Cheng Y, Duan RD (2006) Intestinal alkaline sphingomyelinase hydrolyses and inactivates platelet-activating factor by a phospholipase C activity. Biochem J 394: $299-308$

Yang S, Lin HZ, Hwang J, Chacko VP, Diehl AM (2001) Hepatic hyperplasia in noncirrhotic fatty livers: is obesity-related hepatic steatosis a premalignant condition? Cancer Res 61: 5016-5023

Yang Y, Nemoto EM, Harvey SA, Subbotin VM, Gandhi CR (2004) Increased hepatic platelet activating factor (PAF) and PAF receptors in carbon tetrachloride induced liver cirrhosis. Gut 53: $877-883$

Zalatan JG, Fenn TD, Brunger AT, Herschlag D (2006) Structural and functional comparisons of nucleotide pyrophosphatase/phosphodiesterase and alkaline phosphatase: implications for mechanism and evolution. Biochemistry 45: $9788-9803$ 